\title{
Implementation of Character Education Management and Establishment of Religiosity Values in Learners
}

\author{
Muhammad Nasir \\ Muhammadiyah University of \\ Parepare \\ drshmnasirmpd@gmail.com
}

\author{
Tawany Rahammah \\ Muhammadiyah University of \\ Parepare \\ twn_unm@yahoo.com
}

\author{
Amaluddin \\ Muhammadiyah University of \\ Parepare \\ amaluddin1965@gmail.com
}

\begin{abstract}
The management of education is too much in giving to the thinking of learners has been created human with split personality. Graduates today tend to be secular, materialistic, rationalistic, hedonistic, and mentally less developed and lacking in emotional intelligence. Based on this, character education is very appropriate to be launched in all lines and levels of education. This study aims to provide character education management formulation at State Senior High School in Parepare City, to provide solutions of urgent religiosity values will be formed on the learners, to apply character education management model that is relevant to the establishment of religious values of State Senior High School students. This research was done using qualitative research type with case study as research design. The locale of the study was conducted at State Senior High in Parepare City, South Sulawesi Province during March 2018 to May 2018. The data in this study is divided into two, namely primary data and secondary data. The data source in this study consists of the main data source in the form of words and actions, as well as additional data sources in the form of documents. Character education is one way to form a person to internalize good moral quality in the family, school, and community.
\end{abstract}

Keywords: implementation, management, education, character, religious values, learners

\section{INTRODUCTION}

A human is the most perfect creature that God created in this world because of its superiority and noblest beings than any other creatures. Humans can think, can do a job despite lacking of good physical or intelligence, and also have passions that can be directed to a better direction, because humans are born innocent like a blank paper. The surrounding environment can affect one's good and bad behavior. The environment is one factor that is influential to individual's character building, so are the physical and socio-psychological environment [1]-[2]. The environment is also sometimes used as a benchmark in the building of individual behavior or character. If the environment is not good, a person can be negatively affected, meanwhile, if the environment is good, a person will likely to be positively affected. However, it also depends significantly on each human's character [3].
One of the founding fathers of the nation, as well as the first president of the Republic of Indonesia, Bung Karno asserted: "This nation must be built by prioritizing character building because character building will make Indonesia a great nation, advanced and glorious, and dignified. If the character building is not performed, Indonesia will be a coolie. Education is an important thing for human survival [4]. A man without education like a vehicle that has no wheels will never progress.

Education in general aims to form and develop human resources to be reliable and intact for the creation of a superior nation. An education system can be said to be qualified if the learning process that is held interesting and challenging for learners so as to foster the spirit of learning [5]. Education is not only producing a person who has intellectual intelligence but also a person who has a commendable personality that is reflected in positive actions for the creation of noble civilization of the nation.Character education is very important because Indonesian people need a reliable, moral, intelligent and competitive person in facing the global world [6].

Educational institutions, especially schools are seen as a strategic place for the character building of learners.The term "character" is etymologically understandable from a number of languages."Character" (Latin) means an instrument of narcissism, "Charessin" (French) means to engrave, "watek" (Java) means the feature of wanci, "character" (Indonesia) means an innate character that affects behavior [7]. From this sense, the character is a nature of psychology, personality, morals or character that characterizes a person or a group of people, while broadly, the character is defined as human nature in general where human beings have many properties that depend on the factor of its own life. The character is the values of human behavior associated with the one God, the self, fellow human beings, the environment, and nationality embodied in thoughts, attitudes, feelings, words, and deeds based on religious norms, laws, manners, culture, and customs [8]-[9].

\section{METHOD}

This research was done using a qualitative research type with case study as research design. The locale of the study is at Senior High School in Parepare City, South Sulawesi Province, Indonesia. The data in this study is divided into two, namely primary data and secondary data. The data source in this study consists of the main 
data source in the form of words and actions, as well as additional data sources in the form of documents. The participants who become the main data source/research informants are the students of State Senior High School and the teachers.

Researchers act as participative observers and indepth interviews. Data collection techniques used were observation, interview, documentation, and field notes. Observation activities conducted to obtain data about the character education management that is relevant to the establishment of religious values of State Senior High School students in Pare-pare City. Interview activities aimed to obtain data about teachers' understanding of character education, constraints, and solutions in the implementation of character education at the school, while the documentation is used to obtain data about learning activities that are done with the management of character education management and the establishment of religious values in order to instill the character values of learners.

\section{RESULT}

The Act No. 20 of 2003 on the national education system character education is, in fact, an important position, it can be seen from the national educational goals that state that the National Education function is to develop the ability and form the character and civilization of dignified nation in order to educate the life of the nation. Also, it aims to the development of potential learners to be a human being who believes and cautious to God who is omnipotent. Learners also encouraged to be noble, healthy, knowledgeable, capable, creative, independent, and become a democratic citizen and responsible, but during this learning process that occurs only emphasize on the cognitive abilities of children so that the educational domain of characters listed in the national education objectives are little or no touched at all.It is evident that graduation standards for elementary and secondary school levels still provide a greater percentage of the National Examination results than the overall evaluation results of all subjects.

The character education is not a material that can only be recorded and memorized and cannot be evaluated in the short term, but character education is a learning applied in all activities of students both in school, community, and the home environment through the process of habituation, exemplary, and done in continuous. Therefore, the success of character education is a shared responsibility between school, community, and parents.Evaluation of the success of character education cannot be assessed by formative or summative tests recorded in scores but the benchmark of successful character education is the formation of learners with character of morally, culturally, politely, religiously, creatively, innovatively applied throughout one's life.

Therefore, there is certainly no proper evaluation tool and can instantly demonstrate the success of character education. Character education is needed for the students in the city of Parepare today, especially at National
Senior High School in Parepare City which has experienced degradation is quite apprehensive. Religious education is one of the materials that aim to improve noble character and spiritual values in children.This shows that religious education has an important role in implementing character education in school. Thus, religious education becomes one of the compulsory subjects of elementary, secondary, and college level. Then the school should be able to organize religious education optimally by applying religious values in the school environment that is done by all teachers and learners together and continuous.It is also very interesting if the school is able to prepare the curriculum by applying religious values that are reflected in each subject. Basically, religious education focuses on internalizing attitudes and personality based on the teachings of religion in all the joints of student life later, so that the attribution of religious values should be listed in.

Values are something that is seen as worthyin human life, which affects attitude of life. Meanwhile, the character according to Hermawan Kartajaya is characteristic of the original and rooted in the individual personality and is the engine of how someone acts, behave and say, and respond to something.The subject of Islamic Education is one of the three subjects required for each type, pathway, and level of education (Pancasila Education, Religious Education, and Civic Education), in accordance with article 12 chapter V Law no. 20 The year 2003: "Every learner in every educational unit is entitled to receive religious education in accordance with his or her religion and is taught by a religious educator." So, one that will answer the improvement of quick implementation in improving the religious values is on the subjects of religion and activities that welding on the improvement of morals or attitudes of learners.

The character education teaches the habits manifested in management through way of thinking and behavior that helps individuals to live and work together as a family, community, and state, also help them to make responsible decisions.In other words, character education teaches the child to think intelligently and activates the midbrain naturally. In order to instil a good character in the students, educational institutions or each school should establish school culture in order to familiarize the character that will be formed.School culture in the formation of this character must be continuously built and developed by all parties involved in the process of education at school.The values that underlie behavior, traditions, daily habits, and symbols must be practiced by all the citizens of the school, and the community around the school. The aspects of formulation that can be done for characters are the aspects of morality, religion, and psychology.All three become an integral aspect of character education. Beyond that, there is a social dimension that needs to be understood and recommended for further review in the next paper.

There are two basic messages of religion: first, giving messages and suggestions so that someone has the vision and meaning of life that comes from the awareness of 
faith.We are all from God and will return to God so that whatever we do in this worldly life must be accounted for later life. Secondly, with the understanding and appreciation of religion, a person grows into a good person who will always spread peace and benefit for others. The Prophet Muhammad peace be upon Him said, "I was sent by God with a mission to teach noble morality for a human.'In other words, it is said: The best of man is the best of morality and the most benefit for others. Thus, religious values are not a set of norms that are conveyed only in the form of lectures, but rather into living values that are jointly guarded and will be perceived when is done. Even the value will be attached to Habit and Positive Character.

\section{CONCLUSION}

Based on the results of research and discussion, it can be concluded that the implementations of religious character values in character education are as follows:

Teacher's thinking about the importance of religiosity in character education is one of the underlying sources of character education and is very important to be instilled to the students because with the provision of a strong religion, which is built early on will strengthen the moral foundation of learners at National Senior High School in Parepare City in the future. Also, students will not be easily affected by bad things.

The role of schools in supporting the implementation of religious character values in character education is to provide facilities that are used to support the implementation of programs held in schools, to give permission to teachers who have ideas to organize an activity program, to support the existing activities in the out of school that aims to instill good character in learners, as well as to provide good role models for students.

The Implementation of the value of religiosity through the implementation and formulation of the best in character education through self-development program consisting of routine activities at National Senior High School in Parepare City, spontaneous activities undertaken by teachers on learners, exemplars provided by teachers, and the conditioning of the school created in such a way. Implementation through the subject by inserting it in the subject matter or moral messages of the teacher and through the school culture consisting of the existing culture in the classroom, school, and outside the school.

\section{REFERENCES}

[1] D. Al Hamdani, "The character education in islamic education viewpoint," $J$. Pendidik. Islam, 2016

[2] Y. Rochwulaningsih, "The Role of Social and Cultural Values in Public Education in Remote Island: a Case Study in Karimunjawa Islands, Indonesia," KOMUNITAS Int. J. Indones. Soc. Cult., 2015.

[3] Y. L. Rahmi, "The Implication of Islamic Character Education and Minangkabau Culture to Biological Learning Achievement," in Proceeding of International Conference On Research, Implementation And Education Of Mathematics And Sciences 2014, 2014.

[4] K. Harto, "Developing Character Internalization Model In Islamic Education Through Value Clarification Technique," Madania J. Kaji. Keislam., 2015.

[5] A. Pascasarjana, U. Ar-Raniry, and B. Aceh, "Optimalisasi Pendidikan Karakter Melalui Ekstrakurikuler Di Smp Negeri 1 Labuhan Haji Barat Aceh Selatan Optimalize Character Education Through Extracurricular In Smp Negeri 1 Labuhan Haji Barat Aceh Selatan," DAYAH J. Islam. Educ. Januari, 2018.

[6] J. Dakir, M. Y. Hj Othman, A. H. Tamuri, Z. Stapa, S. A. Yahya, and S. I. @ I. Maheran, "Islamic Education and Level of Character Internalization of Secondary School Students in Malaysia," Mediterr. J. Soc. Sci., 2015.

[7] S. A. Khan, "Role of Islamic Education in character building of young generation: A case study from secondary level institutes of Karachi," Educ. Res. Int., 2014.

[8] B. Bensaid and S. Ben Tahar Machouche, "Exploring the relationship between Islamic religious learning and community," Multicult. Educ. Technol. J., 2013.

[9] B. B. Riedel, "The character conjuncture: Islamic education and its social reproduction in the United States," 2009. 